\title{
Various Clinical Presentation of Post-Transplant Lymphoproliferative Disorder in Head and Neck: A Case Series of 3 Patients
}

\author{
Hee-jung Kim ${ }^{1}$, Sang Joon Choi ${ }^{2}$, Young Hyeh $\mathrm{Ko}^{2}$, and Nayeon Choi ${ }^{1}$ \\ ${ }^{1}$ Departments of Otorhinolaryngology-Head and Neck Surgery, ${ }^{2}$ Pathology and Translational Genomics, Samsung Medical Center, \\ Sungkyunkwan University School of Medicine, Seoul, Korea
}

\section{다양한 임상양상을 보이는 두경부의 이식 후 림프증식성 질환: 3 예}

김희정 ${ }^{1} \cdot$ 최상준 $^{2} \cdot$ 고영혜 $^{2} \cdot$ 최나연 ${ }^{1}$

성균관대학교 의과대학 삼성서울병원 이비인후과학교실, ${ }^{1}$ 병리학교실 ${ }^{2}$

\author{
Received January 26, 2017 \\ Revised March 20, 2017 \\ Accepted March 24, 2017 \\ Address for correspondence \\ Nayeon Choi, MD \\ Department of Otorhinolaryngology- \\ Head and Neck Surgery, \\ Samsung Medical Center, \\ Sungkyunkwan University \\ School of Medicine, 81 Irwon-ro, \\ Gangnam-gu, Seoul 06351, Korea \\ Tel $+82-2-3410-3579$ \\ Fax $+82-2-3410-3879$ \\ E-mail chlskduschoi@naver.com
}

The outcome of solid organ and bone marrow transplantation has been dramatically improved with the development of immunosuppressive agent. However, the use of immunosuppressive agents could increase the risk of malignancies such as post-transplant lymphoproliferative disorder (PTLD). PTLD is regarded as the lymphoid malignancy of patients using immunosuppressive agents, and it could present diverse and non-specific symptoms. It involves various organs including the tonsil, adenoid, lymph node, and the brain. Because of its poor prognosis, an early suspicion of pathologic diagnosis is crucial for the treatment of PTLD. In this report, we demonstrate the case of three pediatric patients who had been treated for PTLD of various clinical presentations by early suspicion and pathologic diagnosis.

Korean J Otorhinolaryngol-Head Neck Surg 2018;61(10):536-40

Key Words Head and neck · Immunosuppressive agent ·

Post-transplant lymphoproliferative disorder.

\section{서 론}

이식 후 림프증식성 질환(post-transplant lymphoproliferative disorder, PTLD)은 장기 이식 후 면역억제제를 복용하 는 환자들에게 생길 수 있는 질환으로, 악성 종양으로 분류 되기도 한다. ${ }^{1-3)} \mathrm{PTLD}$ 의 유병률은 면역억제제를 복용하는 환자에서 20\%까지 보고되며, 2년 생존율은 70 80\%로 알려 져 있다. ${ }^{2,4)}$

PTLD는 무증상부터 발열, 체중 감소 등의 비특이적인 임 상 양상을 보인다. ${ }^{2,5,6)}$ 두경부에서는 전염성 단핵구증과 같은

This is an Open Access article distributed under the terms of the Creative Commons Attribution Non-Commercial License (https://creativecommons.org/licenses/by-nc/4.0) which permits unrestricted non-commercial use, distribution, and reproduction in any medium, provided the original work is properly cited.
염증성 질환과 감별이 어렵고, 증상만으로 조기에 의심하는 것이 어렵다. 따라서, PTLD의 조기 진단을 위해서는 위험인자 파악을 통한 임상적 의심과 조직 검사를 통한 확진이 필수적 이다. 하지만, 소아 환자에서는 증상의 표현이 어렵고, 조직검 사 시 전신마취를 요하기 때문에, 진단이 늦어지기 쉽다. 본 증 례에서는 코골이, 호흡곤란 등의 드문 증상을 나타내는 3명 의 소아 PTLD 환자에서, 조기에 조직학적 진단 및 치료를 하 였기에 보고하고자 한다.

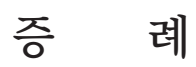

\section{증 례 1}

생후 7개월 남아는 선천성 담도 폐쇄증을 진단받고 생체 공 
여자 간 이식 수술을 받은 후 면역억제제(tacrolimus $0.5 \mathrm{mg}$, 1 일 2회) 복용을 시작하였다. 생후 12 개월째, 점차 심해지는 코골이와 식이 섭취량 감소로 내원하였고, 당시 상기도 감염 소견은 없었고 혈역학적 징후는 정상이었다. 내시경 검진 및
컴퓨터전산화단층촬영에서 아데노이드 비대가 관찰되었다 (Fig. 1A and B). 림프증식성 질환을 감별하기 위하여 시행한 검사상, 혈액 Epstein-Barr virus(EBV) DNA polymerase chain reaction(PCR)은 간 이식 전 음성에서 8.74 copies/uL
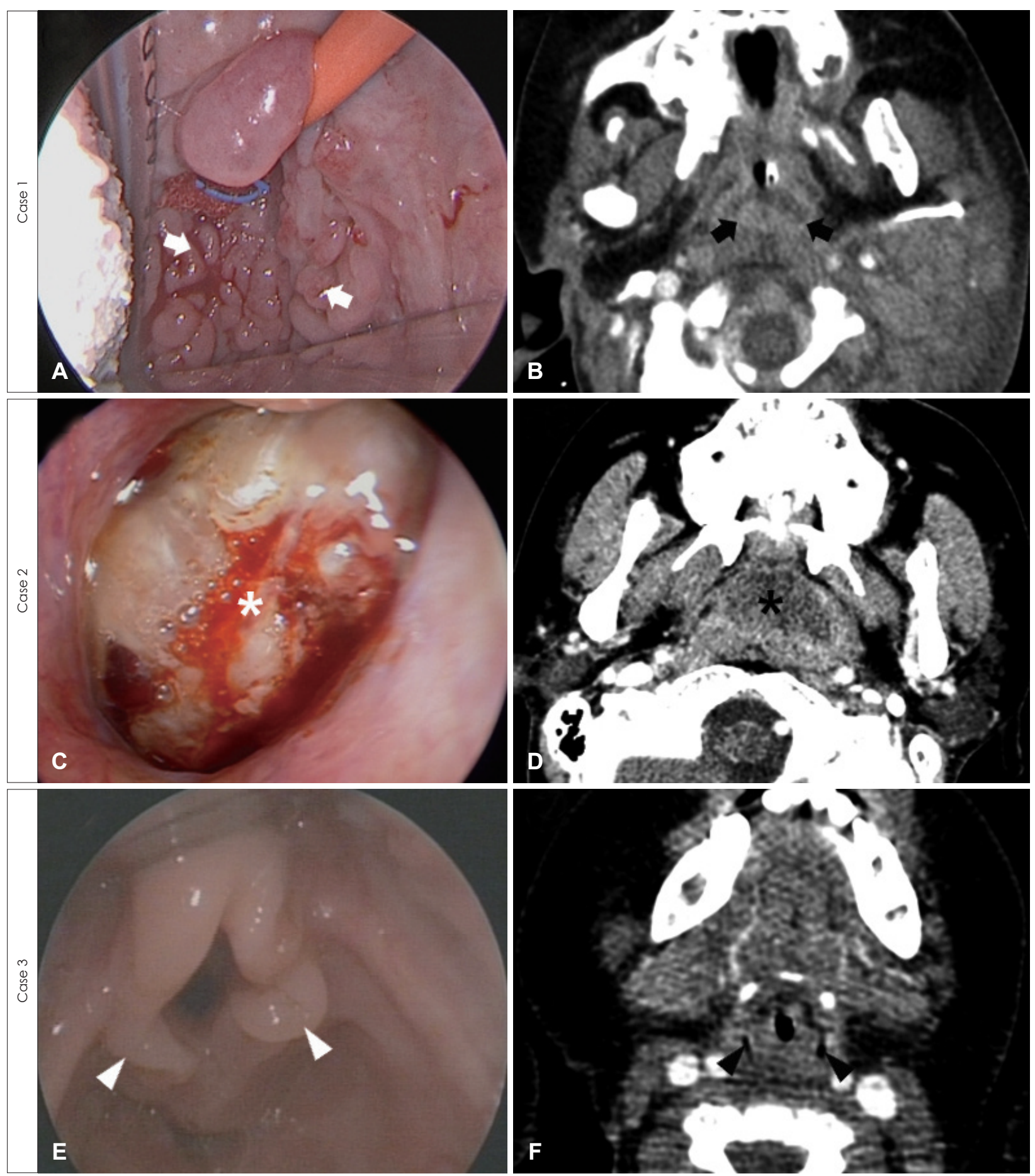

Fig. 1. Case 1. Endoscopic image showed adenoid hypertrophy (A, white arrows) and computed tomography (CT) showed enhanced lymphoid enlargement of adenoid (B, black arrows). Case 2. Nasal endoscopic image demonstrated hypertrophic adenoid with purulent discharge (C, white asterisk) and CT showed adenoid enlargement with abscess formation (D, black asterisk). Case 3 . Laryngoscopic evaluation revealed hypertrophy of aryepiglottic fold ( $E$, white arrowheads) and laryngeal soft tissue hypertrophy was suspicious on CT ( $F$, black arrowheads). 
로 증가하였고, 전신 마취하에서의 아데노이드 조직검사는 PTLD(T-lineage, EBV negative)로 진단되었다(Fig. 2A). 이 에, 면역억제제를 하루 $0.25 \mathrm{mg}, 2$ 회로 감량하고, rituximab $160 \mathrm{mg}$ 을 1 주일 간격으로 총 4회 정맥 주사하였다. 혈액 $\mathrm{EBV}$ DNA PCR은 rituximab 4회 치료 후 음전되었으며, 이후 면역 억제제를 다시 $0.5 \mathrm{mg}$ 으로 증량하여 생후 28 개월까지 특이 소 견 없이 경과 관찰 중이다.

\section{증 례 2}

15세 남자 환자는 후복벽에 발생한 포상 연부 육종(alveolar soft part sarcoma)으로 항암치료 후, 종양 절제술 및 추가 방 사선 치료를 받았다. 하지만, 4개월 뒤, 후복벽 종양이 지속적 으로 관찰되어, 고용량 항암 치료 및 말초혈 조혈모세포 이
식을 받고 면역억제제(cyclosporin $50 \mathrm{mg}, 1$ 일 2회)를 복용 하였다. 이식 2개월 뒤 반복되는 목 통증 및 비루, 코골이를 호소하였고, 검진상 편도 및 아데노이드 비대와 삼출(Fig. $1 \mathrm{C}$ and $\mathrm{D})$ 이 관찰되었다. 혈액 $\mathrm{EBV} \mathrm{DNA} \mathrm{PCR}$ 은 이식 전 음 성이었으나, $64 \mathrm{copies} / \mathrm{uL}$ 로 증가되었다. 림프증식성 질환이 의심되고, 반복되는 편도염과 발열이 있었기 때문에, 전신 마 취하 양측 편도 절제술 및 아데노이드 조직검사를 시행하였 다. 조직검사에서 PTLD(B-cell lineage, polymorphic type) 로 진단되어(Fig. 2B), rituximab $650 \mathrm{mg}$ 을 1주 간격으로 총 3회 주사하였고, 그 후 EBV DNA PCR은 음전되었다. 2개월 뒤, 이전과 같은 증상을 보여 시행한 검사상 $\mathrm{EBV} \mathrm{DNA} \mathrm{PCR}$ 은 2 copies/uL이고, 아데노이드 조직검사는 PTLD(monomorphic; diffuse large B-cell lymphoma type) 소견이었다

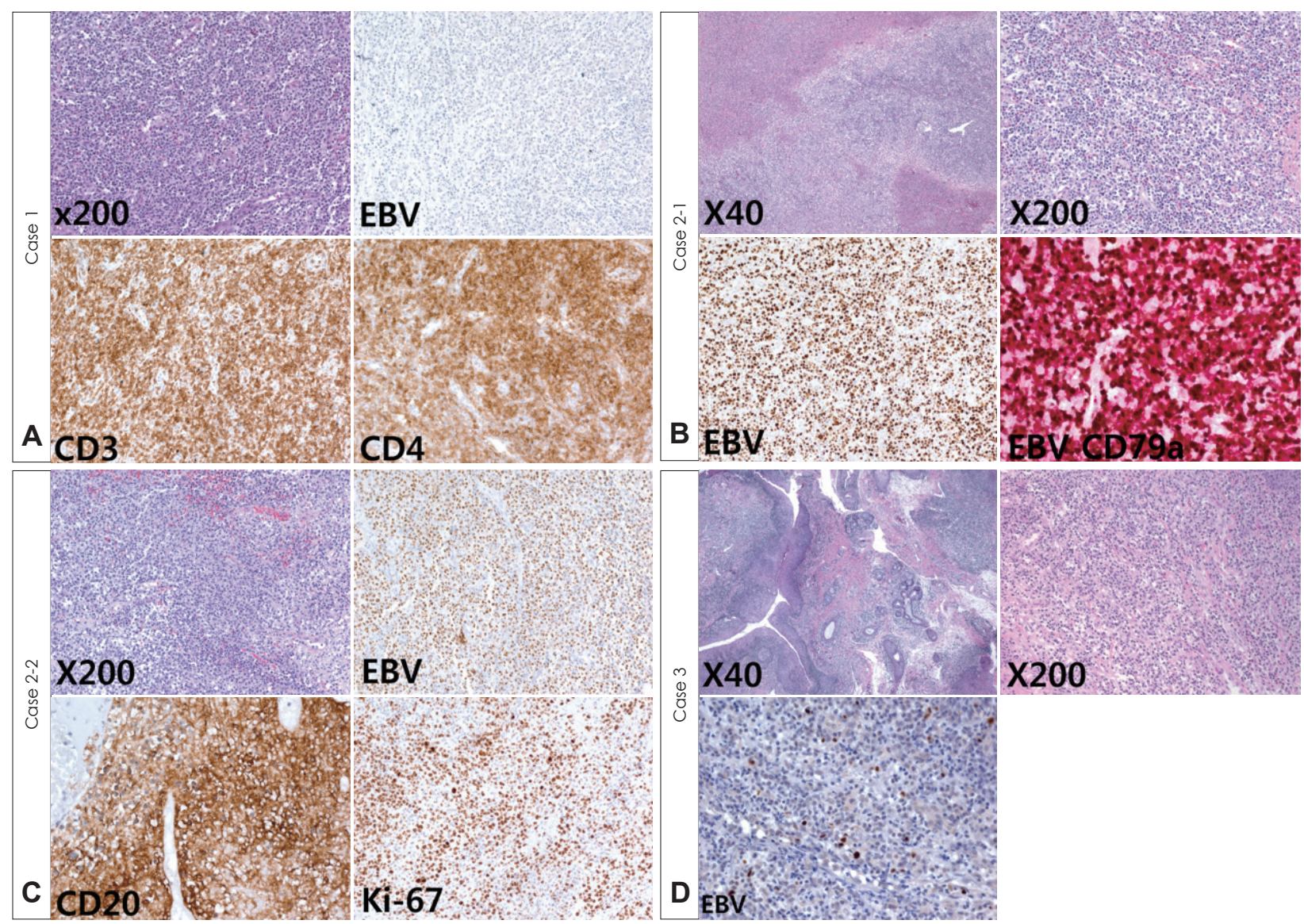

Fig. 2. Case 1 was diagnosed with T-cell lineage EBV negative post-transplant lymphoproliferative disease (PTLD). Effacement of normal tonsillar architecture by lymphoid cell proliferation (H\&E stain, $\times 200)$, negative for EBV-encoded RNA in situ hybridization $(\times 200$ ), and positive immunohistochemical stain of CD3 and CD4 $(\times 200)$ were observed $(A)$. Case 2-1 had pathologic diagnosis as B-cell polymorphic type PTLD. Loss of tonsillar architecture with necrosis (H\&E, $\times 40)$, small and large cell mixture of lymphocytes, immunoblasts and plasma cells $(\mathrm{H} \& \mathrm{E}, \times 200)$ were showed. EBV-encoded RNA in situ hybridization was positive $(\times 200)$ and EBV plus CD79a double staining showed majority of EBV-positive cells are positive for CD79a $(\times 200)(B)$. Case 2-2 had relapse PTLD which was diagnosed with PTLD of monomorphic diffuse large B-cell lymphoma. Sheets of monotonous large lymphoid cells $(\mathrm{H} \& \mathrm{E}, \times 200)$ and positive for EBV-encoded RNA in situ hybridization $(\times 200)$ were detected. CD20 $(\times 200$, CD20) was positive and Ki-67 $(\times 200$, Ki-67) was also positive in more than $70 \%$ of tumor cells $(\times 200)(C)$. Case 3 was diagnosed with early lesion plasmacytic hyperplasia type PTLD. Maintenance of tonsillar architecture with plasmacytic proliferation was showed (H\&E, $\times 40, \times 200)$, and EBV-encoded RNA in situ hybridization was positive in few tumor cells ( $\times 200$, EBV) (D). RNA: ribonucleic acid, EBV: Epstein-Barr virus. 
(Fig. 2C). 이에 항암치료[R-cyclophosphamide, hydroxydaunorubicin, vincristine, prednisolone(CHOP) 3 cyles]를 시행 하였고, 그 후 $\mathrm{EBV} \mathrm{DNA} \mathrm{PCR}$ 은 음전되고 농성 비루 및 삼 출액도 호전되었지만, 포상 연부 육종의 우측 대퇴골, 척추 및 폐 전이 소견을 보여 대증 치료를 시행하던 중, 8 개월 뒤 사 망하였다.

\section{증 례 3}

생후 9개월 남아는 선천성 담도 폐쇄증으로 사체 공여자 간 이식술 시행 후 면역 억제제(tacrolimus $0.5 \mathrm{mg}, 1$ 일 2회)를 복 용하였다. 생후 12 개월, 천명(stridor)을 동반한 호흡곤란이 발 생하여 이비인후과에 의뢰되었다. 혈액 $\mathrm{EBV} \mathrm{DNA} \mathrm{PCR}$ 은 이 식 전 음성에서 $30 \mathrm{copies/uL로} \mathrm{상승되어} \mathrm{있었으며,} \mathrm{내시경} \mathrm{검}$ 진 상 편도와 아데노이드에는 정상 소견이었다. 컴퓨터전산 화단층촬영에서는 후두 부위의 조영 증강을 동반한 경한 연 부 조직 부종 소견이 보였다(Fig. 1F). 이에 전신 마취하에 기 도 평가를 하였고, 피열후두개 주름의 비대(Fig. 1E)가 보여 시행한 조직검사에서 PTLD(early lesion, plasmacytic hyperplasia type)로 진단되었다(Fig. 2D). 면역억제제를 0.4 $\mathrm{mg}$ 으로 감량 후 한 달 째, 호흡곤란 증상이 완화되고, 혈액 $\mathrm{EBV}$ DNA PCR은 7 copies/uL로 감소되어, 외래 추적 관찰 중이다.

\section{고 찰}

장기 이식 후 면역억제제를 쓰는 환자는 정상 인구군에 비 해 악성 종양이 발생할 확률이 45배 증가하게 되며, 이 중 대 표적인 질병이 림프종으로 분류되기도 하는 PTLD이다. ${ }^{7)}$ 면 역억제제를 사용하는 환자에서 PTLD의 유병률은 1 20\%까 지 보고되고 있으며, ${ }^{3,4}$ 성인보다 소아에서 호발한다고 알려져 있다.5) 소아의 경우 신장 이식 시 2 3\%, 간 이식 시 5 10\%, 심 장 이식 시 $6 \%$, 폐 이식 시 $15 \%$, 소장이식 시 $20 \%$, 조혈모세포 이식 시 $1 \%$ 에서 PTLD가 발생한다고 보고되고 있다. ${ }^{5,8)}$

PTLD의 증상은 서혜부 및 경부의 만져지는 종괴, 발열, 체 중감소 등으로 비특이적이다. ${ }^{2,5)}$ 본 증례와 같은 두경부의 PTLD는 발열, 목 통증부터 호흡 곤란, 코골이와 같은 다양 한 증상을 보인다. 이처럼 PTLD는 다양한 임상증상을 보이 기 때문에, 위험인자를 평가하여 조기에 의심하고 적절한 검 사 및 치료를 하는 것이 중요하다. 대표적인 위험인자로 면역 억제제 투여, 이식 전 EBV의 혈청 음성 상태, 어린 나이가 있 다. 1,25,9) 본 증례와 같이, 면역억제제를 사용하는 대부분의 소 아 환자는 이식 전 $\mathrm{EBV}$ 혈청 음성 상태이고, 나이가 어려 고 위험군에 해당된다.
특히 면역억제제 복용을 시작할 당시의 $\mathrm{EBV}$ 혈청 음성인 경우 PTLD의 발병률은 양성인 경우에 비해 50배로 증가한 다. ${ }^{5)}$ 본 증례에서는 모든 환자에서 면역억제제를 투여하기 전 에, 혈액 EBV DNA PCR을 시행하였고, 모두 PTLD 발병 고 위험군인 혈청 음성 상태였다. 또한, EBV DNA PCR의 수치 는 PTLD 발병을 알기 위한 모니터링 검사로도 사용되므로, ${ }^{2}$ 본 증례에서도 주기적으로 $\mathrm{EBV} \mathrm{DNA} \mathrm{PCR}$ 을 시행하여, 수치 가 증가할 경우 $\mathrm{EBV}$ 감염이나 PTLD 등의 질환을 평가할 수 있도록 하였다. 하지만, 대부분의 연구에서 EBV DNA PCR은 치료 반응과 연관성이 낮다고 알려져 있다. ${ }^{10)}$

$\mathrm{PTLD}$ 는 영상의학적 진단이 어렵고 치료가 늦어질 경우 사 망까지 이를 수 있어, 조기에 생검을 통한 병리학적 진단이 필 요하다. ${ }^{2,11,2)}$ 본 증례에서는 비특이적인 증상을 보이는 소아 환자에서 PTLD의 위험인자가 있는 경우에 조기에 전신 마취 하 조직검사를 하여 PTLD를 진단하였다.

$\mathrm{PTLD}$ 의 치료법은 아직까지 정립된 바가 없으며, 조직학적 아형, 환자의 상태, PTLD가 진단된 장기 등에 따라 개별적으 로 치료하게 된다. 치료의 기본이 되는 것은 면역억제제를 감 량하는 것이며, 항암 또는 면역치료제(rituximab)가 사용된다. PTLD 치료의 기본이 되는 것은 면역억제제를 조절하는 것 과 항암 또는 면역치료제를 사용하는 것이다. 일부 보고에서 는 면역억제제만 감량함으로써, PTLD가 완전 관해되는 것 을 관찰하였다. ${ }^{10)}$ 하지만, 대부분의 환자에서는 면역억제제 감량만으로는 불충분한 효과를 보이기 때문에, 다양한 항암 및 면역치료제가 시도되고 있다. 이 중 가장 효과적이고 안전 하여 표준 치료제로 자리잡은 것이 항 CD20 항체인 rituximab이다.6) 면역억제제 감량 및 rituximab 치료에 반응이 없 는 경우에는, antracycline을 기반으로 하는 항암 치료(CHOP) 를 하기도 한다. ${ }^{13)}$

PTLD는 조직학적으로 크게 네 가지로 분류된다. 첫째, early lesions are plasmacytic hyperplasia or infectious mononucleosis-like PTLD의 경우, EBV positive B-cell의 초기 병변으로 조직의 기본 구조가 보존되어 있는 것이 특징 이다. 둘째, polymorphic PTLD의 경우, 초기 병변과 유사하 나 조직의 기본 구조를 일부 파괴하는 양상으로, early lesion 과 쉽게 감별이 가능하다. 셋째, monomorphic PTLD의 경우, $\mathrm{PTLD}$ 의 약 $50 \%$ 정도를 차지하는 조직학적 분류로, $\mathrm{B}-\mathrm{cell}$ origin(non-Hodgkin lymphoma) 혹은 T-cell origin의 lymphoma로 분류된다. 마지막으로, classical Hodgkin lymphoma-type PTLD는 monomorphic PTLD의 일종이나 특이 한 조직학적 구조를 가지고 있어 따로 분류한 상태를 일컫는 다. 이에 맞추어 상기 증례 환자들의 조직학적 분류를 나누어 볼 수 있었다. ${ }^{14}$ 
요약하면, 두경부에 발생하는 PTLD는 증상이 비특이적이 고, 편도염과 같은 염증성 질환과 감별이 어려워, 조기에 위 험인자를 파악하고 조직검사를 하는 것이 중요하다. 본 증례 에서 저자들은 다양한 임상 소견을 보이는 PTLD 고위험군 소아 환자에서 전신마취하 조직검사를 통한 조기 진단 및 치 료를 하였기에 보고하였다.

\section{REFERENCES}

1) Boubenider S, Hiesse C, Goupy C, Kriaa F, Marchand S, Charpentier B. Incidence and consequences of post-transplantation lymphoproliferative disorders. J Nephrol 1997;10(3):136-45.

2) Mynarek M, Schober T, Behrends U, Maecker-Kolhoff B. Posttransplant lymphoproliferative disease after pediatric solid organ transplantation. Clin Dev Immunol 2013;2013:814973.

3) Gottschalk S, Rooney CM, Heslop HE. Post-transplant lymphoproliferative disorders. Annu Rev Med 2005;56:29-44.

4) Webber SA, Naftel DC, Fricker FJ, Olesnevich P, Blume ED, Addonizio $\mathrm{L}$, et al. Lymphoproliferative disorders after paediatric heart transplantation: a multi-institutional study. Lancet 2006;367(9506): 233-9.

5) Shroff R, Rees L. The post-transplant lymphoproliferative disorder-a literature review. Pediatr Nephrol 2004;19(4):369-77.

6) Evens AM, David KA, Helenowski I, Nelson B, Kaufman D, Kircher SM, et al. Multicenter analysis of 80 solid organ transplantation recipients with post-transplantation lymphoproliferative disease: outcomes and prognostic factors in the modern era. J Clin Oncol 2010; 28(6):1038-46.
7) Engels EA, Pfeiffer RM, Fraumeni JF Jr, Kasiske BL, Israni AK, Snyder JJ, et al. Spectrum of cancer risk among US solid organ transplant recipients. JAMA 2011;306(17):1891-901.

8) Weinstock DM, Ambrossi GG, Brennan C, Kiehn TE, Jakubowski A. Preemptive diagnosis and treatment of Epstein-Barr virusassociated post transplant lymphoproliferative disorder after hematopoietic stem cell transplant: an approach in development. Bone Marrow Transplant 2006;37(6):539-46.

9) Lim WH, Russ GR, Coates PT. Review of Epstein-Barr virus and post-transplant lymphoproliferative disorder post-solid organ transplantation. Nephrology (Carlton) 2006;11(4):355-66.

10) Starzl TE, Nalesnik MA, Porter KA, Ho M, Iwatsuki S, Griffith BP, et al. Reversibility of lymphomas and lymphoproliferative lesions developing under cyclosporin-steroid therapy. Lancet 1984;1(8377): 583-7.

11) Loren AW, Porter DL, Stadtmauer EA, Tsai DE. Post-transplant lymphoproliferative disorder: a review. Bone Marrow Transplant 2003;31(3):145-55.

12) Mucha K, Foroncewicz B, Niemczyk K, Ziarkiewicz-Wróblewska B, Stanisławek-Sut O, Zieniewicz K, et al. Tonsil enlargement after liver transplantation in adults--reason enough for tonsillectomy? Two cases of tonsillar posttransplantation lymphoproliferative disease. Liver Transpl 2007;13(6):918-23.

13) Elstrom RL, Andreadis C, Aqui NA, Ahya VN, Bloom RD, Brozena $\mathrm{SC}$, et al. Treatment of PTLD with rituximab or chemotherapy. Am J Transplant 2006;6(3):569-76.

14) Nalesnik MA. The diverse pathology of post-transplant lymphoproliferative disorders: the importance of a standardized approach. Transpl Infect Dis 2001;3(2):88-96. 